Pena Justisia: Media Komunikasi dan Kajian Hukum

Vol. 17, No. 2, 2017, 1-16

Artikel Hasil Penelitian

\title{
Pelaksanaan Standarisasi Pelayanan Pariwisata Halal dalam Pengembangan Pariwisata di Nusa Tenggara Barat
}

\author{
Adrian Adi Hamzana \\ Badan Perencanaan Pembangunan Daerah Provinsi Nusa Tenggara Barat, Indonesia
}

Artikel Diterima:

27 Oktober 2017

Artikel Disetujui:

13 November 2017

Artikel Diterbitkan:

15 Desember 2017

*Korespondensi Penulis: adrianadihazmana@gmail.com

\begin{abstract}
West Nusa Tenggara Province received 3 (three) awards at The World Halal Tourism Awards 2016. The government then appointed West Nusa Tenggara as one of the national halal tourism destinations and as one of 10 priority destinations that have a vision of "World's Best Halal Tourism and Cruise Destination". Local Government take steps by passing Regional Regulation No. 2 Year 2016 on Halal Tourism. This study is an empirical law study, with a statutory approach, a conceptual approach, and a sociological approach. Based on the results of the research, the implementation of standardization of halal tourism services in West Nusa Tenggara on destinations conducted by the Department of Culture and Tourism through the fulfillment of public facilities according to halal tourism. The standardization of halal tourism industry is done by the Department of Culture and Tourism, the Department of Industry and Commerce and the Health Service, and the Ulema Council of Indonesia-West Nusa Tenggara as the institution authorized to issue halal certificates. Factors affecting the standardization of halal tourism services are legal factors (legislation), legal structure (law enforcement), supporting facilities or factors, community factors and cultural factors.
\end{abstract}

Keywords: Implementation, Standardization, Halal Tourism.

\section{Abstrak}

Provinsi NTB mendapatkan 3 (tiga) penghargaan di ajang The World Halal Tourism Awards 2016. Pemerintah kemudian menunjuk NTB sebagai salah satu destinasi wisata halal nasional dan sebagai salah satu dari 10 (sepuluh) destinasi prioritas yang memiliki visi "World's Best Halal Tourism and Cruise Destination". Pemerintah Daerah mengambil langkah dengan mengesahkan Peraturan Daerah No. 2 Tahun 2016 tentang Pariwisata Halal. Penelitian ini merupakan penelitian hukum empiris, dengan pendekatan perundang-undangan, pendekatan konseptual, dan pendekatan sosiologis. Berdasarkan hasil penelitian, pelaksanaan standarisasi pelayanan pariwisata halal di NTB pada destinasi dilakukan oleh Dinas Kebudayaan dan Pariwisata NTB melalui pemenuhan fasilitas umum sesuai pariwisata halal. Standarisasi pada industri pariwisata halal dilakukan Dinas Kebudayaan dan Pariwisata, Dinas Perindustrian dan Perdagangan dan Dinas Kesehatan, serta MUI-NTB sebagai lembaga non-pemerintah berwenang mengeluarkan sertifikat halal. Faktor-faktor yang mempengaruhi standarisasi pelayanan pariwisata halal di NTB adalah faktor hukum (peraturan perundang-undangan), struktur hukum (penegak hukum), faktor sarana atau fasilitas pendukung, faktor masyarakat dan faktor kebudayaan.

Kata Kunci: Pelaksanaan, Standarisasi, Pariwisata Halal. 
2 Pena Justisia: Media Komunikasi dan Kajian Hukum Vol. 17, No. 2, 2017

\section{PENDAHULUAN}

Usaha mewujudkan tujuan Negara berdasar Pembukaan UUD NRI 1945 diaktualisasikan melalui peningkatan pertumbuhan ekonomi diantaranya adalah dengan menggali potensi sumber daya dalam negeri, salah satunya melalui pemanfaatan sumber daya sebagai sektor pariwisata. Pariwisata merupakan sektor yang menjanjikan untuk meningkatkan pertumbuhan ekonomi Indonesia. Pertumbuhan sektor ini bisa membantu membuka keran investasi swasta, menciptakan lapangan kerja, menambah ekspor, memandu investasi infrastruktur. Menurut World Travel and Tourism Council, tiap \$1 juta yang dibelanjakan untuk sektor travel dan pariwisata bisa mendukung 200 lapangan kerja dan $\$ 1,7$ juta PDB bagi Indonesia. ${ }^{1}$ Saat ini, sektor pariwisata Indonesia berkontribusi untuk kira-kira 4\% dari total perekonomian. Pada tahun 2019, Pemerintah Indonesia ingin meningkatkan angka ini dua kali lipat menjadi 8\% dari PDB, mengimplikasikan bahwa dalam waktu 4 tahun mendatang, jumlah pengunjung perlu ditingkatkan dua kali lipat menjadi kira-kira 20 juta. $^{2}$ Sementara itu, Di tahun 2019 akhir RPJM periode kepemimpinan Presiden Joko Widodo, target wisatawan asing berkunjung berjumlah 20 juta, wisatawan nusantara atau pengunjung dari dalam negeri berjumlah 275 juta orang. Dari sektor pariwisata ini ditargetkan akan menghasilkan devisa 260 Trilyun. $^{3}$

Pembangunan pariwisata merupakan salah satu sektor pembangunan di bidang ekonomi yang dapat mempercepat pertumbuhan ekonomi dan kesejahteraan masyarakat. Badan Perencanaan Nasional Indonesia (Bappenas) dalam Visi Dan Arah Pembangunan Jangka Panjang (PJP) Tahun 2005-2025 menuliskan bahwa: ${ }^{4}$ Kepariwisataan dikembangkan agar mampu mendorong kegiatan ekonomi dan meningkatkan citra Indonesia, me-

1 The World Bank, "Laporan Ekonomi Triwulanan Indonesia, Oktober 2016: Tekanan Mereda”, Dikutip dari laman: http://www.worldbank.org/in/country/indonesia/publi cation/indonesia-economic-quarterly-october-2016.

2 "Industri Pariwisata Indonesia", Dikutip dari laman: https://www.indonesia-investments.com/id/bisnis/ industri-sektor/pariwisata/item6051?

3 Sekretariat Kabinet RI, "Tahun 2017 Kita Genjot Sektor Pariwisata", Dikutip dari laman: http://setkab.go.id/ tahun-2017-kita-genjot-sektor-pariwisata/ ningkatkan kesejahteraan masyarakat lokal, serta memberikan perluasan kesempatan kerja. Pengembangan kepariwisataan memanfaatkan keragaman pesona keindahan alam dan potensi nasional sebagai wilayah wisata bahari terluas di dunia secara arif dan berkelanjutan, serta mendorong kegiatan ekonomi yang terkait dengan pengembangan budaya bangsa.

Sebagai wujud kepastian hukum yang menjadi salah ciri Negara hukum, ${ }^{5}$ kepariwisataan diatur melalui Undang-Undang Nomor 10 Tahun 2009 tentang Kepariwisataan (selanjutnya disingkat UU No. 10 Tahun 2009). Disamping sebagai elemen pertumbuhan ekonomi, kepariwisataan juga bertujuan memberikan perlindungan terhadap nilai-nilai agama, budaya yang hidup dalam masyarakat, kelestarian dan mutu lingkungan hidup, serta kepentingan nasional, sehingga kepariwisataan merupakan bagian integral dari pembangunan nasional yang dituntut untuk dilakukan secara sistematis, terencana, terpadu, berkelanjutan, bertanggung jawab. ${ }^{6}$

Pengaturan tentang sertifikasi halal dalam memberikan perlindungan konsumen muslim terdapat pada Undang-Undang Nomor 33 Tahun 2014 Tentang Jaminan Produk Halal (JPH). Undang-undang ini mengatur hak dan kewajiban pelaku usaha yang tertuang dalam pasal 23 sampai dengan pasal 27. Dalam pasal 26 pelaku usaha yang memproduksi produk dari bahan yang berasal dari bahan yang diharamkan sebagaimana dimaksud dalam pasal 18 dan pasal 20 dikecualikan dari mengajukan permohonan sertifikat halal. ${ }^{7}$

Berkaitan dengan perkembangan kepariwisataan, Bambang Sunaryo berpandangan bahwa pembangunan pariwisata bertitik tolak pada 4 (empat) pilar yaitu; destinasi, pemasaran (promosi), industri pariwisata dan kelembagaan. Ke-

4 Badan Perencanaan Pembangunan Nasional, "Visi Dan Arah Pembangunan Jangka Panjang (PJP) Tahun 2005 2025", Dikutip dari laman: https://www.bappenas.go.id/ files/1814/2057/0437/RPJP_2005-2025.pdf

7 Asri, Asri. "Perlindungan Hukum Bagi Konsumen Terhadap Produk Pangan Yang Tidak Bersertifikat Halal." Jurnal IUS (Kajian Hukum dan Keadilan) 4.2 (2016). HIm. 8 
empat pilar pembangunan pariwisata tersebut akan menjadi pedoman dasar dalam penyelenggaraan pembangunan di bidang kepariwisataan. Salah satu subsektor yang sekarang menjadi perhatian pada sektor pembangunan kepariwisataan adalah Pariwisata Halal. ${ }^{8}$ Pariwisata Halal merupakan "icon" baru pembangunan pariwisata yang harus dikembangkan dan memerlukan perhatian, karena diharapkan dapat mengundang dan menarik wisatawan, baik wisatawan domestik (nusantara) maupun wisatawan mancanegara.

Indonesia berhasil meraih 12 penghargaan bergengsi pada sektor halal tourism di ajang The World Halal Tourism Awards 2016.9 Pada tahun 2016, Pemerintah melalui Kementerian Pariwisata menunjuk 3 (tiga) provinsi di Indonesia sebagai destinasi (tujuan) wisata halal, yakni Sumatera Barat, Aceh, dan Nusa Tenggara Barat (selanjutnya disingkat NTB). ${ }^{10}$

Penunjukan NTB sebagai destinasi pariwisata halal dan sebagai salah satu daerah persiapan berdasar pula pada penghargaan World's Best Halal Beach Resort Winner: Novotel Lombok Resort \& Villas, dan World's Best Halal Honeymoon Destination Winner: Sembalun Valley Region, West Nusa Tenggara. ${ }^{11}$ Menyikapi pengembangan Pariwisata Halal, Pemerintah Daerah NTB melakukan pembentukan regulasi sebagai pedoman dan legalitas dalam pelaksanaan pariwisata halal, hal ini terlihat pada mulai diterbitkannya Peraturan Gubernur Nomor 51 Tahun 2015 tentang Wisata Halal (selanjutnya disebut Pergub NTB No.1 Tahun 2015) dan kemudian diperkuat melalui Peraturan Daerah Provinsi Nusa Tenggara Barat Nomor 2 Tahun 2016 tentang Pariwisata Halal (selanjutnya disingkat Perda NTB No. 2 Tahun 2016).

\section{RUMUSAN MASALAH}

Berdasarkan latar belakang masalah tersebut di atas, dirumuskan permasalahan sebagai berikut: pertama, bagaimanakah pelaksanaa standarisasi pelayanan pariwisata halal dalam pengembangan pariwisata di NTB?; kedua, apakah faktor-faktor yang mempengaruhi standarisasi pelayanan pariwisata halal dalam pengembangan pariwisata halal di NTB?

\section{METODE PENELITIAN}

Penelitian ini menggunakan penelitian hukum empiris, dengan model penelitian yuridis normatif, 12 yaitu penelitian yang mengkaji dan menganalisa efektifitas hukum dan penerapan hukum dalam masyarakat, asas-asas hukum dan norma-norma hukum yang akan diaplikasikan sebagai kaidah atau norma yang merupakan pato-kan berperilaku manusia yang sewajarnya, de-ngan mengkaji ketentuan hukum yang berlaku, atau penelitian yang dilakukan dengan mengkaji ketentuan perundang-undangan (in abstracto) serta melihat fakta-fakta hukum yang terjadi di lapangan (inconcreto). Pendekatan yang digunakan dalam penelitian ini adalah adalah pendekatan perundang-undangan (statute approach), pendekatan konsep (conceptual approach), dan pendekatan sosiologis (sosiological approach). ${ }^{13}$

\section{PEMBAHASAN}

Pelaksanaan Standarisasi Pelayanan Pariwisata Halal Dalam Pengembangan Pariwisata di Nusa Tenggara Barat (NTB)

Pengaturan Pariwisata Halal dalam Perda NTB No. 2 Tahun 2016

Perda NTB No. 2 Tahun 2016 tentang Pariwisata halal merupakan pelaksanaan dari kekhususan daerah sebagaimana diatur dalam UU No. 23 Tahun 2014 tentang Pemerintahan Daerah.

11 "The World Halal Tourism Awards 2016 Winners", Dikutip dari laman: http://itwabudhabi.com/halal-awards/2016winners.html

12 Mukti Fajar dan Yulianto Achmad, Dualisme Penelitian Hukum Normatif-Empiris, Pustaka Pelajar, Yogyakarta, 2010, hlm. 47

13 Peter Muhamad Marzuki, 2005, Penelitian Hukum, Cet.ke7, Kencana Prenada Media Group, Jakarta, hlm.93 
4 Pena Justisia: Media Komunikasi dan Kajian Hukum Vol. 17, No. 2, 2017

Pada Pasal 236 ayat (3) huruf b memuat ketentuan bahwa materi Peraturan Daerah merupakan penjabaran lebih lanjut ketentuan peraturan perundang-undangan yang lebih tinggi. Maka dari itu, Perda NTB No. 2 Tahun 2016 juga lahir berdasarkan ketentuan UU No. 10 Tahun 2009 tentang Kepariwisataan sebagai pedoman umum dan sebagai dasar pembangunan pariwisata halal. Sebagaimana yang dimuat dalam UU No. 10 Tahun Pasal 20 huruf c menyatakan bahwa wisatawan berhak mendapatkan perlindungan hukum dan keamanan, kemudian Pasal 23 ayat (1) diantaranya mengamanatkan bahwa Pemerintah dan Pemerintah Daerah berkewajiban memberikan perlindungan hukum dan menciptakan iklim yang kondusif untuk perkembangan usaha pariwisata yang meliputi terbukanya kesempatan yang sama dalam berusaha, memfasilitasi, dan memberikan kepastian hukum.

Berdasarkan ketentuan umum yang ditentukan oleh UU No. 10 Tahun 2009 tersebut, maka dapat dimaknai pula bahwa langkah Pemerintah Provinsi NTB membentuk Perda NTB No. 2 Tahun 2016 merupakan sebuah langkah perlindungan hukum kepada wisatawan dan sebagai pemenu- han kewajiban yang ditentukan oleh UU No. 10 Tahun 2009. Perlindungan tersebut ditunjukan pada dasar pertimbangan yang dimuat dalam konsideran Perda NTB No. 2 Tahun 2016 menyatakan bahwa usaha Pariwisata Halal merupakan konsep yang mengintegrasikan nilai-nilai syari'ah ke dalam kegiatan pariwisata dengan menyediakan fasilitas dan pelayanan yang sesuai dengan ketentuan syariah. Hal ini memiliki arti bahwa perlindungan hukum terhadap wisatawan muslim yang memiliki kewajiban berdasarkan tuntunan agama juga memiliki kebutuhan ibadah dengan tetap melakukan kegiatan pariwisata. Sehingga Perda NTB No. 2 Tahun 2016, disamping mengedepankan aspek kemanfaatan ekonomi, juga memberikan keamanan dan kenyamanan pelayanan kepada wisatawan agar dapat menikmati kunjungan wisata dengan aman, halal dan juga dapat memperoleh kemudahan bagi wisatawan dan pengelola dalam kegiatan kepariwisataan.

Berdasarkan ketentuan dalam Perda No. 2 Tahun 2016, maka pariwisata halal dikelompokan kedalam 2 (dua) jenis, yaitu destinasi dan industri pariwisata. Lebih jelas dimuat dalam gambar berikut:

\section{Gambar 1. Pariwisata Halal dalam Perda NTB No. 2 Tahun 2016}

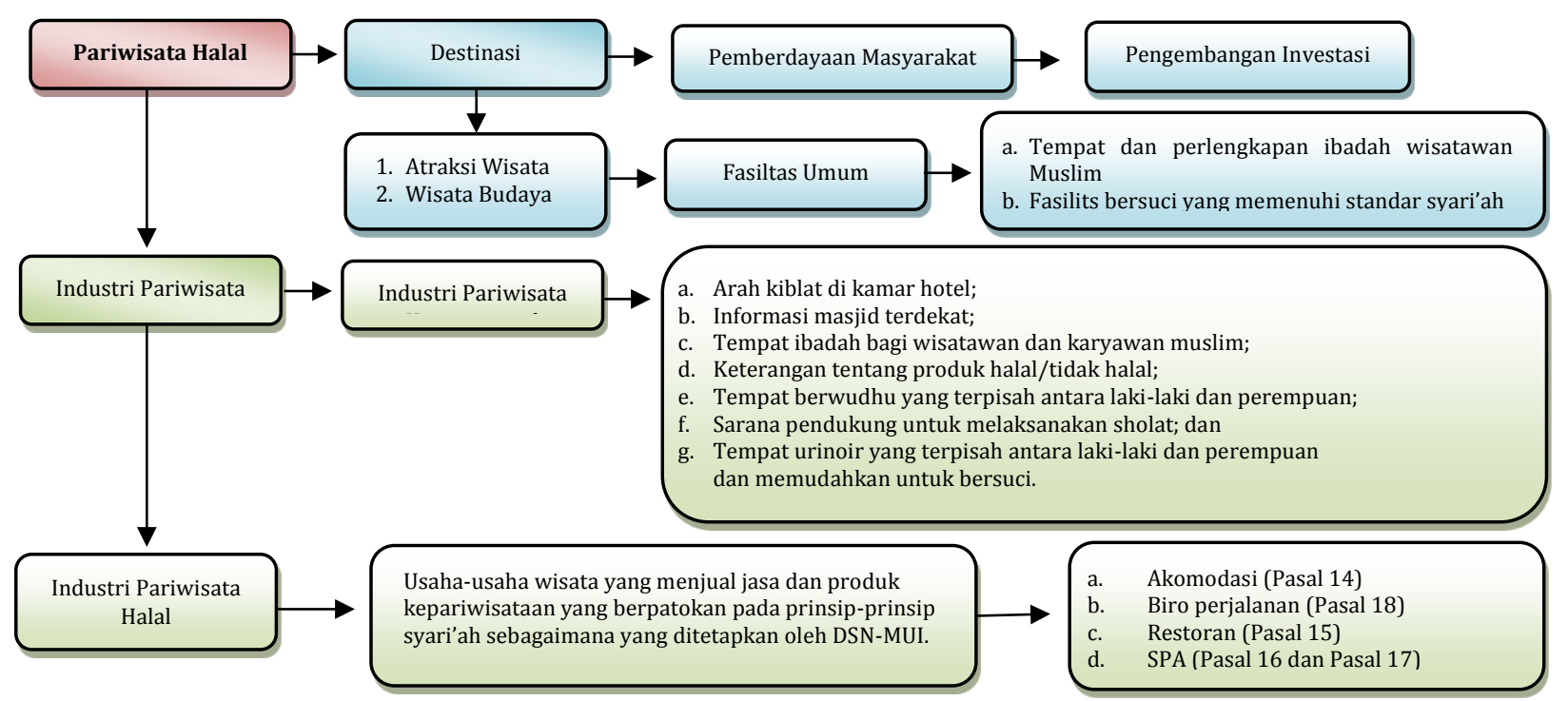

Sumber: Diolah oleh Penulis Berdasar Perda NTB No.2 Tahun 2016 


\section{Mekanisme Sertifikasi Halal di MUI-NTB}

Berdasarkan hasil penelitian pada MUINTB, Administrasi Sertifikasi halal digambarkan dalam diagram alur sebagai berikut: ${ }^{14}$

Gambar 2. Proses Sertifikasi Halal MUI-NTB

\begin{tabular}{|c|c|c|}
\hline Pre Audit & Proses Audit & Pasca Audit \\
\hline $\begin{array}{l}\text { - Registrasi } \\
\text { - Akad } \\
\text { Sertifikasi }\end{array}$ & $\begin{array}{l}\text { - Pengecekan: } \\
\text { Bahan, Produk, } \\
\text { Fasilitas, } \\
\text { Formula, dll } \\
\text { - Verifikasi } \\
\text { Implementasi } \\
\text { SJH: } \\
\text { Kebijakan Halal, } \\
\text { Tim Halal, } \\
\text { Prosedur, dll }\end{array}$ & $\begin{array}{l}\text { - Laporan } \\
\text { Berkala } \\
\text { - Ijin Pergantian } \\
\text { Bahan }\end{array}$ \\
\hline
\end{tabular}

Sumber: LPPOM MUI-NTB, 2017

Adapun prosedur umum sertifikasi halal yaitu: 15

Proses Pre Audit:

a. Perusahaan baru/pengembangan produk/ fasilitas dan perpanjangan melakukan pendaftaran;

b. Mengisi borang data pendaftaran;

c. Membayar biaya pendaftaran dan biaya akad sertifikasi halal.

Proses Audit:

a. Mengisi dokumen yang disyaratkan:

1. Manual SJH

2. Diagram alir proses produksi

3. Data pabrik

4. Data produk

5. Data bahan

6. Dokumen bahan

7. Data matrix bahan

b. Pemeriksaan Kecukupan dokumen

c. Audit

d. Rapat Komisi Fatwa

Kemudian, berkaitan dengan prosedur pemberian sertifikasi halal yaitu: ${ }^{16}$

14 Hasil Penelitian pada Lembaga Pengkajian Pangan, Obatobatan dan Kosmetika, Majelis Ulama Indonesia - Nusa Tenggara Barat, Tanggal 5 September 2017. Dalam Materi Teti Indrawati, Sertifikasi Produk Halal Bagi Usaha Pariwisata di NTB, a. Melalui fasilitas pemberian serifikasi halal bekerja sama dengan SKPD Provinsi NTB: Diskop UMKM, Disperindag dan Dispar dan Kebudayaan Provinsi NTB;

b. Melalui pengajuan langsung ke LPPOM MUI Provinsi NTB melalui sistem manual;

c. Melalui penerapan Sistem Pelayanan Sertifikasi Halal Online (Cerol=SS23000).

Kewajiban pelaku usaha yang mengajukan sertifikasi halal yaitu: ${ }^{17}$

a. Memberikan informasi secara benar, jelas dan jujur;

b. Memisahkan lokasi, tempat dan alat penyembelihan;

c. Memisahkan pengolahan, penyimpanan, pengemasan, pendistribusian, penjualan dan penyajian antra produk halal dan tidak halal;

d. Memiliki penyelia halal;

e. Melaporkan perubahan komposisi bahan pada MUI.

Kewajiban pelaku usaha yang mengajukan sertifikasi halal yaitu: 18

a. Kebijakan halal

b. Tim manajemen halal

c. Pelatihan dan edukasi

d. Bahan

e. Produk

f. Fasilitas produksi

g. Prosedur tertulis untuk aktifasi kritis

h. Kemampuan telusur (traceability)

i. Penanganan produk yang tidak memenuhi kriteria

j. Audit internal

k. Kaji ulang manajemen

\section{Sektor Pariwisata Halal di NTB}

Hasil penelitian pada Dinas Kebudayaan dan Pariwisata Provinsi NTB, menunjukan bahwa sektor pariwisata halal pada jenis destinasi di NTB belum terdapat yang menerapkan konsep wisata

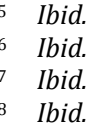


6 Pena Justisia: Media Komunikasi dan Kajian Hukum Vol. 17, No. 2, 2017

syariah secara utuh. Supri Kariyadi selaku Kepala Seksi Pariwisata Halal Bagian Destinasi menyampaikan kembali dengan mendasarkan pada uraian Kepala Dinas Kebudayaan dan Pariwisata NTB bahwa: ${ }^{19}$

"Proses sertifikasi halal untuk Disbudpar berkoordinasi dengan Disperindag, Dinas Kesehatan dan diluar itu bersama MUINTB, kami juga intens melakukan seminar dan sosialisasi bersama-sama. Untuk tahun 2016 dan 2017 fokus pariwisata halal memang sebagian besar perencanaan dan tahapan awal pembangunan, jadi belum terdapat pariwisata halal yang benar-benar murni, masih kalah dengan wisata konvensional biasa, tetapi upaya kami memperhatikan kebutuhan wisatawan muslim dengan memberikan petunjuk dan informasi yang detail. Pemerintah daerah NTB sedang mengembangkan wisata pantai khusus dengan konsep halal beach. Di pantai ini wisatawan laki-laki dan perempuan akan dipisah. Halal beach kita sekarang sedang tahapan pengerjaan, tahun ini sudah kita mulai pembangunan awalnya, ada dua kawasan pantai di pulau Lombok yang akan dikembangkan menjadi konsep pantai halal, di antaranya di kawasan Meninting, Lombok Barat dan kawasan Mandalika, Lombok Tengah. Di lokasi pantai halal ini nantinya akan ada pembatas permanen yang memisahkan antara wisatawan laki-laki dan wisatawan perempuan. Makanan yang disediakan di lokasi tersebut adalah makanan yang halal".

Sedangkan Ketua BPPD-NTB, Afan Ahmad berkaitan dengan peran BPPD-NTB dalam pelaksanaan promosi pariwisata halal adalah:20

"Sebelum memenangkan penghargaan World's Best Halal di Dubai tahun 2015, Lombok selama bertahun-tahun sudah lebih dahulu dikenal karena memiliki banyak sekali pantai yang indah dan eksotis. Dengan adanya penghargaan pariwisata halal terhadap Lombok maka promosi wisata tahun 2016 khususnya lebih digencarkan, peran BPPD-NTB sesuai dengan arahan Pemerintah Daerah, kerjasama juga dilakukan dengan Asita-NTB, guna melakukan promosi kepada dunia internasional. Pariwisata halal mendapatkan perhatian yang lebih terutama setelah disahkannya Perda Pariwisata halal NTB, kita juga dilibatkann dalam proses penyusunan, sehingga amanat Perda selalu menjadi prioritas kami di tahun 2017 dalam melakukan promosi pariwisata halal, walaupun pariwisata halal masih banyak kendala pada standarisasinya dalam pelaksanaanya, sebenarnya promosi dan pengembangan destinasi harus berimbang."

Sedangkan pada aspek industri, berdasarkan hasil penelitian pada MUI-NTB, data yang terhimpun masih terbatas pada aspek restoran, ditunjukan sebagai berikut:

\section{Gambar 3. Data Sertifikasi Halal Provinsi NTB Tahun 2012-2016}

\begin{tabular}{|c|c|c|c|c|c|}
\hline \multirow{2}{*}{$\begin{array}{c}\text { Jenis } \\
\text { Usaha }\end{array}$} & \multicolumn{5}{|c|}{ Tahun } \\
\cline { 2 - 5 } & 2012 & 2013 & 2014 & 2015 & 2016 \\
\hline UMKM & 239 & 226 & 180 & 75 & 269 \\
\hline $\begin{array}{c}\text { Rumah } \\
\text { Makan }\end{array}$ & --- & --- & --- & 20 & 200 \\
\hline $\begin{array}{c}\text { Restoran } \\
\text { Hotel }\end{array}$ & --- & --- & ---- & 5 & 75 \\
\hline $\begin{array}{c}\text { Restoran } \\
\text { Non } \\
\text { Hotel }\end{array}$ & --- & --- & ---- & 75 & 100 \\
\hline \begin{tabular}{c} 
Jumlah \\
\hline
\end{tabular} & 239 & 226 & 180 & 175 & 664 \\
\hline
\end{tabular}

Sumber: LPPOM MUI-NTB, 2017

Berdasarkan ketentuan pengaturan dalam Perda NTB No. 2 Tahun 2016, maka dalam sektor pariwisata halal di Provinsi NTB terbagi kedalam 2 (dua) jenis, yaitu destinasi dan industri. Dari hasil penelitian, menunjukan bahwa pelaksanaan standarisasi pariwisata halal di NTB sudah mulai menunjukan peningkatan pada aspek restoran. Signifikansi peningkatan angka pelaksanaan stan-

20 Hasil wawancara dengan Ketua BPPD-NTB, Afan Ahmad, Rabu, 6 September 2017 
darisasi pariwisata halal terjadi pada tahun 2016, bersamaan pula dengan dikeluarkannya Perda NTB No. 2 Tahun 2016 tentang Pariwisata Halal.

Rauhun selaku Ketua LPPOM MUI-NTB ber-

kaitan dengan pertumbuhan sertifikasi hal menyampaikan bahwa: ${ }^{21}$

"Proses sertifikasi dilakukan MUI bekerjasama dengan Disperindag NTB, serta Dinas Kesehatan kabupaten dan kota di NTB. Majelis Ulama Provinsi Nusa Tenggara Barat telah menerbitkan 1496 sertifikasi halal sejumlah Hotel, Restoran Dan UMKM diseluruh kabupaten kota yang ada di NTB. Jumlah tersebut hasil sertifikasi halal mulai tahun 2012 sampai 2016, yang dirilis sejak tanggal 19 April 2017, yang terbagi 3 kelompok, yang pertama sertifikasi halal rumah makan, warung, catering dan restoran hotel, yang ke dua, halal rumah makan, warung, catering dan non restoran hotel dan yang ke tiga produk olahan (UMKM) Untuk tahun selanjutnya, diharapkan akan terus meningkat dengan banyaknya kesadaran msayarakat pentingnya mendapatkan sertifikasi halal. Pada tahun 2016, Lembaga Pengkajian Pangan, Obat, dan Kosmetika LPPOM MUI NTB sudah menerbitkan 676 sertifikasi halal untuk restoran hotel sebanyak 28 sertifikat, restoran nonhotel sebanyak 107 sertifikat, rumah makan dan catering sebanyak 262, dan produk olahan UMKN sebanyak 279. perlu dicatat bahwa, NTB termaksud yang paling banyak dari provinsi di indonesia yang mendapatkan sertifkasi halal, selain jakarta, kalau dibandingkan dengan daerah diseluruh indonesia, termaksud yang memilki capaian memang cukup besar, dengan jumlah yang ada".

Berkaitan dengan akomodasi hotel disampaikan oleh Rauhun bahwa: ${ }^{22}$

“... masih banyak juga hotel dan restauran yang belum mengurus sertifikasi halal, meski juga telah disiapkan subsidi dari pemerintah daerah melalui APBD. Dari 200 lebih hotel di NTB mulai dari bintang dua hingga lima, sebagian besar masih belum memiliki sertifikat label halal dari MUI. Saat ini baru ada 22 hotel bintang di Provinsi

21 Hasil wawancara dengan Ketua LPPOM MUI-NTB, Rauhun, 22 Ibid.
NTB yang sudah dikeluarkan label sertifikat halal. Begitu juga dengan restauran dan lesehan yang cukup banyak di NTB juga masih minim yang mengurus sertifikat halal. Saya berharap kepada para pelaku usaha untuk memiliki kesadaran mengurus sertifikasi halal sebagai salah satu dukungan terhadap kemajuan pariwisata di NTB sebagai destinasi halal dunia. MUI bersama SKPD teknis terkait terus sosialisasikan tentang sertifikasi halal ini. Tentunya kami juga berharap ada pro aktif dari pelaku usaha dan pengusaha untuk mengurus sertifikasi halal ini."

Berdasarkan uraian hasil wawancara di atas, maka dalam penyelenggaraan pariwisata halal berdasarkan pedoman atau ketentuan Perda NTB No. 2 Tahun 2016 masih belum berjalan secara optimal, sertifikasi halal masih didominasi oleh aspek restoran, sedangkan untuk destinasi masih terbatas pada fasilitas umum yang disesuaikan dengan kebutuhan wisatawan muslim dengan penambahan petunjuk dan kelengkapan lain sesuai kebutuhan ibadah wisatawan muslim. Begitu pula dengan akomodasi, biro perjalanan dan SPA. Masih belum menunjukan peningkatan pelayanan secara signifikan. Hal tersebut sejalan dengan yang dinyatakan oleh Paul Scholten bahwa hukum tidak pernah dijalankan pada hakekatnya telah menjadi hukum. ${ }^{23}$

Mewujudkan NTB menjadi "World's Best Halal Tourism and Cruise Destination", diperlukan upaya penegakkan hukum yang efektif dan efisien, karena penegakkan hukum merupakan tahap penting dalam tetap menjaga supremasi hukum sebagai negara hukum. Penegakan hukum dalam pariwisata halal merupakan adalah proses dilakukannya upaya tegaknya atau berfungsinya normanorma hukum yang mengatur pariwisata halal secara nyata sebagai pedoman penyelenggaraan pariwisata halal. Penegakan hukum pariwisata halal merupakan usaha untuk mewujudkan ide-ide dan konsep-konsep hukum yang diharapakan menjadi kenyataan

23 Satjipto Rahardjo, 1996, Ilmu Hukum, Bandung: Citra Aditya Bakti, , hlm.69 
8 Pena Justisia: Media Komunikasi dan Kajian Hukum Vol. 17, No. 2, 2017
Faktor-Faktor Yang Mempengaruhi Standarisasi Pelayanan Pariwisata Halal Dalam Pengembangan Pariwisata Halal Di NTB Faktor Hukum (Peraturan Perundang-Undangan)

Lahirnya Pergub NTB No.1 Tahun 2015 kemudian Perda NTB No. 2 Tahun 2016 menandai optimalisasi peran pemerintah daerah dalam meningkatkan pelayanan pariwisata halal. Perda NTB No. 2 Tahun 2016 merupakan peraturan perundang-undangan yang mengatur khusus pariwisata halal dan secara tegas menentukan ketentuanketentuan dalam penyelenggaraan pariwisata halal yang menentukan standar umum yang harus dipenuhi oleh destinasi dan industri baik yang konvensional maupun khusus pariwisata halal.

Khusus pada sektor produk halal, semenjak UU No.33 Tahun 2014 tentang Jaminan Produk Halal dikeluarkan, diikuti pula peningkatan terhadap sertifikasi halal di Indonesia, termasuk Provinsi NTB sebagaimana yang ditunjukan data sertifikasi halal pada uraian di atas. Hasil penelitian yang dilakukan pada Dinas Kebudayaan dan Pariwisata Provinsi NTB juga diperkuat oleh Agus Hidayatullah selaku Kepala Bidang Destinasi yang menyampaikan bahwa:24

"Potensi pariwisata halal yang dimiliki oleh Provinsi NTB sangat besar. Provinsi NTB merupakan salah satu model wisata halal di Indonesia. Pengembangan pariwisata halal di Provinsi NTB terus dilakukan melalui upaya-upaya seperti Peraturan Daerah Pariwisata Halal yang merupakan pertama di Indonesia yaitu Peraturan Daerah Provinsi NTB No. 2 Tahun 2016 tentang Pariwisata Halal. Peraturan Daerah merupakan elemen utama dalam meningkatkan pariwisata halal, terbukti semenjak Perda ini keluar, kami dinas terkait mengupayakan pembenahan setiap destinasi pariwisata baik atraksi alam dan wisata budaya sesuai standar yang ditetapkan pemerintah salah

24 Hasil wawancara dengan Kepala Bidang Destinasi Dinas Kebudayaan dan Pariwisata Provinsi NTB, Agus Hidayatullah, Senin 11 September 2017.

25 Hasil wawancara dengan Ketua LPPOM MUI-NTB, Rauhun, Selasa, 5 September 2017

26 J.W. Harris, 1993, Legal Philophies, London, UK: Butterworths, hlm.101. dikutip dalam Yusuf Shofie, Jaminan Atas satunya Perda NTB, ini juga dilakukan oleh usaha pariwisata yang mulai membenahi sarana dan fasilitas umum untuk mendukung program prioritas pemerintah".

Sejalan dengan Agus Hidayatullah, Rauhun selaku Ketua LPPOM MUI-NTB menyampaikan bahwa: ${ }^{25}$

"Data ini menunjukan (sambil menunjukan kertas berisi data jumlah sertifikasi halal) antara tahun 2012 sampai dengan 2016 ada peningkatan yang sangat signifikan, ini tidak terlepas dari peraturan pusat tentang jaminan produk halal, ditambah kebijakan pariwisata halal dan Perda pariwisata halal NTB, untuk tahun 2017 ini, datanya belum kami rilis, ada peningkatan melebihi tahun lalu, karena pariwisata halal semakin gencar di NTB"

Berdasarkan paparan di atas, menunjukan bahwa faktor hukum merupakan faktor penting yang berfungsi sebagai pendorong penyelenggaraan dan peningkatan pariwisata halal di NTB. Dalam pandangan Kelsen, hukum mempunyai karakter imperatif. Teori murni hukumnya menganggap elemen paksaan (coercion) sebagai suatu kandungan utama konsep hukum (as an essential ingredient of the concept of law). Ditegaskannya: "hukum adalah perintah perilaku manusia yang dipaksakan" ("law is a coercive order of human behavior"). Paksaan (coercion) tersebut ditentukan oleh tata hukum (the legal order). Sanksisanksi yang diterapkan hukum merupakan sanksisanksi yang berada di bagian luar (outward), yang mengandung perampasan secara paksa kehidupan, kebebasan, atau kepemilikan, atau penjatuhan tindakan lainnya yang dianggap buruk oleh individu yang dikenainya. ${ }^{26}$

Sedangkan Mochtar Kusumaatmadja memandang bahwa: 27

Produk Halal Dari Sudut Pandang Hukum Perlindungan Konsumen, Jurnal Syariah 3, November 2015, hlm. 49-50

27 Mochtar Kusumaatmadja, Konsep-Konsep Hukum Dalam Pembangunan (Kumpulan Karya Tulis) Penerbit Alumni, Bandung, 2002, hlm. 14 
"Hukum merupakan suatu alat untuk memelihara ketertiban dalam masyarakat. Mengingat fungsinya sifat hukum, pada dasarnya adalah konservatif artinya, hukum bersifat memelihara dan mempertahankan yang telah tercapai. Fungsi demikian diperlukan dalam setiap masyarakat, termasuk masyarakat yang sedang membangun, karena di sini pun ada hasil-hasil yang harus dipelihara, dilindungi dan diamankan. Akan tetapi, masyarakat yang sedang membangun, yang dalam difinisi kita berarti masyarakat yang sedang berubah cepat, hukum tidak cukup memiliki memiliki fungsi demikian saja. Ia juga harus dapat membantu proses perubahan masyarakat itu. Pandangan yang kolot tentang hukum yang menitikberatkan fungsi pemeliharaan ketertiban dalam arti statis, dan menekankan sifat konservatif dari hukum, menganggap bahwa hukum tidak dapat memainkan suatu peranan yang berarti dalam proses pembaharuan.

Apabila melihat keberlakuan Perda No. 2 Tahun 2016 tentang Pariwisata Halal berdasar pada hierarki peraturan perundang-undangan, keberadaan Perda NTB No. 2 Tahun 2016 belum diperkuat oleh peraturan perundang-undangan diatasnya (Undang-Undang, Peraturan Presiden, Peraturan Menteri) yang mengatur dan memberikan penekan khusus pada sektor pariwisata halal, sebelumnya pariwisata halal pernah di atur melalui Peraturan Menteri Pariwisata Dan Ekonomi Kreatif Nomor 2 Tahun 2014 Tentang Pedoman Penyelenggaraan Usaha Hotel Syariah (Berita Negara Republik Indonesia Tahun 2014 Nomor 74). Sehingga perlu dilakukan penguatan lebih lanjut pada semua aspek pariwisata halal, baik destinasi yang terdiri dari atraksi alam dan wisata budaya maupun industri yang terdiri dari akomodasi, restoran, biro perjalanan, dan SPA. Disamping itu juga perlu dilakukan harmonisasi ataupun sinkronisasi dengan peraturan perundang-undangan terkait diantaranya seperti pengaturan kewenangan berdasar UU No. 23 Tahun 2014 tentang Pemerintah daerah agar memberikan ruang terhadap pemerintah daerah dan lebih memperkuat posisi Perda No. 2 Tahun 2016 dalam rangka

28 Hasil wawancara dengan Ketua BPPD-NTB, Afan Ahmad, Rabu, 6 September 2017 penegakannya dan dapat berfungsi secara maksimal.

\section{Faktor Struktur Hukum (Penegak Hukum)}

Berdasar Perda No. 2 Tahun 2016, kelembagaan di daerah yang terintegrasi di dalam penyelenggaraan pariwisata halal terdiri dari kelembagaan pemerintahan dalam hal ini Dinas Kebudayaan dan Pariwisata Provinsi Nusa Tenggara Barat, dan lembaga non-pemerintah antara lain Dewan Syari'ah Nasional Majelis Ulama Indonesia Nusa Tenggara Barat (DSN-MUI NTB), Badan Promosi Pariwisata Daerah Nusa Tenggara Barat (BPPD-NTB), dan Association of The Indonesian Tours and Travel Agencies (Asita). Lembaga-lembaga tersebut mempangaruhi pelaksanaan pelayanan standarisasi pariwisata halal, dengan peran dan kewenangan yang diberikan, seperti MUINTB, maka peningkatan sertifikasi halal pada tahun 2015 dan 2016 juga tidak dapat mengenyampingkan peran serta MUI-NTB.

Ketua Badan Promosi Pemerintah Daerah (BPPD) NTB, Afan Ahmad memiliki pandangan yang berbeda terhadap pariwisata halal di NTB. Afan Ahmad mengatakan: ${ }^{28}$

“Dengan budaya Islam yang kental, NTB sangat percaya diri menjadi destinasi wisata syariah Indonesia. Program yang diunggulkan sudah jelas bahwa keindahan alam dan budaya menjadi kekuatan NTB sebagai destinasi wisata syariah Indonesia. "Beautiful, spiritual dan diversity. Tiga hal itu ketika kita bicara halal tourism. Dan 92 persen masyarakatnya adalah Muslim, sehingga berkaitan dengan halal tourism itu sudah menjadi bagian dari kehidupan kita. BPPDNTB juga selalu mengedukasi perilaku masyarakat untuk lebih bersabahat dengan turis. Salah satunya dengan membuat iklan layanan masyarakat yang mengajarkan kejujuran dan keramahtamahan. Ini marketing tools nilai-nilai kemanusiaan agar turis Muslim dalam negeri dan mancanegara merasa nyaman dan aman. Namun ada hambatan dan tantangan dalam mengembangkan wisata syariah di NTB. seperti konsep atau definisi wisata syariah yang 
10 Pena Justisia: Media Komunikasi dan Kajian Hukum

Vol. 17, No. 2, 2017

belum jelas, hotel dan restoran belum mendapat sertifikasi halal dari MUI dan belum tersedia lembaga pelatihan kepariwisataan wisata syariah. Masalah sertifikasi halal ini, kebanyakan para pengusaha Muslim di NTB merasa tidak perlu karena apa yang mereka tampilkan sudah halal. Selain itu, bagi mereka biaya sertifikasi itu juga mahal. Sementara arah wisata syariah adalah semua produk yang disajikan harus berserktifikasi halal sebagai wujud pembuktian yang sah. Pemahaman tradisional pengusaha lokal terkait sertifikasi halal ini akan disampaikan kepada pemerintah agar dicari solusinya, kami berharap hambatan sertifikasi halal ini bisa terselesaikan dengan baik, semisal pemerintah pusat mengadakan program intensif bagi pengusaha yang ingin mendapat sertifikasi halal gratis bisa melakukan pendaftaran. Yang terpenting, kami ingin terlebih dahulu mengkomunikasikan kepada pemerintah pusat, di dalam memperjuangkan halal tourism ini harus ada kebijakan yang jelas bagi daerah. Sehingga aturan mainnya yang harus dilakukan di daerah dan implementasinya seperti apa. Diharapkan ada sinkorniasasi antara Kementerian Pariwisata dan Ekonomi Kreatif (Kemenparekraf) dan Dinas Pariwisata NTB. Jangan sampai nanti ada dinas yang kurang setuju dengan program halal tourism itu. Destinasi wisata syariah itu harus benar-benar siap, produk dan paket-paketnya jelas agar sesuai dengan harapan wisatawan itu sendiri."

Berdasarkan uraian Ketua BPPD-NTB diatas, ditemukan faktor masyarakat, faktor hukum dan faktor struktur hukum sebagai faktor penghambat yang mempengaruhi penyelenggaraan pariwisata halal di NTB.

Menurut Soerjono Soekanto, halanganhalangan yang mungkin dijumpai pada penerapan peranan yang seharusnya dari golongnan panutan atau penegak hukum, mungkin berasal dari dirinya sendiri atau dari lingkungan adalah: ${ }^{29}$

1. Keterbatasan kemampuan untuk menempatkan diri dalam peranan pihak lain dengan siapa dia berinteraksi

2. Tingkat aspirasi yang relatif belum tinggi

29 Soerjono Soekanto, 2011, Faktor-Faktor Yang Mempengaruhi Penegeakan Hukum Cet.Ke-10, Raja Grafindo Persada, Jakarta, hlm. 34-35
3. Kegairahan yang sangat terbatas untuk memikirkan masa depan, sehingga sulit sekali untuk membuat proyeksi

4. Kurangnya daya inovatif yang sebenarnya merupakan pasangan konservatisme.

Dengan demikian selain sosialisasi atau penyuluhan pada masyarakat terkait kesadaran hukum masyarakat yang dilakukan oleh Dinas Kebudayaan dan Pariwisata Provinsi NTB dan MUI-NTB. Penguatan mentalitas lembaga pemerintah dan nonpemerintah sangat penting dalam mengoptimalkan penyelenggaraan pariwisata halal. Berdasarkan ketentuan dalam Perda No. 2 Tahun 2016, MUI-NTB merupakan lembaga nonpemerintah yang melakukan sertifikasi halal, sehingga peran MUI-NTB sangat sentral dalam mendukung Dinas Kebudayaan dan Pariwisata Provinsi NTB mendukung pariwisata halal.

\section{Faktor Sarana atau Fasilitas Pendukung}

Berdasarkan pemaparan Ketua LPPOM MUI-NTB, Rauhun bahwa jumlah industri kecil menengah produk olahan pangan yang mengurus sertifikat label halal masih minim. Padahal, pemerintah daerah sudah menyiapkan dana untuk pembiayaan mengurusan sertifkat label halal. Kutipan wawancara sebagai berikut: 30

"Pemerintah sudah menggratiskan biaya pengurusan sertifikat halal. Tapi justru IKM masih minim yang mengurus label halal untuk produk pangan olahan, untuk menggenjot jumlah IKM dan UMKM mengurus label halal, utamanya yang sekarang ini digratiskan oleh pemerintah daerah melalui bantuan dana APBD, hendaknya SKPD teknis terkait memberikan pendampingan kepada pelaku usaha, baik itu IKM dan UMKM dalam mengurus proses yang harus dilalui, utamanya untuk mendapatkan pangan industri rumah tangga yang dikeluarkan oleh Dinas Kesehatan Kabupaten/Kota. Pendampingan kepada pelaku usaha, sangat penting untuk mempermudah pengurusan PIRT. Karena persoalan mendasar yang dialami oleh IKM dan UMKM dalam mengurus sertifikasi halal adalah rata-rata belum mendapatkan PIRT. Sementara un-

30 Hasil wawancara dengan Ketua LPPOM MUI-NTB, Rauhun, Selasa, 5 September 2017 
tuk mendapatkan PIRT, pelaku usaha harus melalui berbagai syarat sesuai ketentuan, baik itu proses produksi, kebersihan, higienitas dan standarisasi bahan baku yang digunakan. Pendampingan bagi IKM dan UMKM untuk mengurus label halal ini sangat baik untuk mempermudah bagi pelaku usaha utamanya dalam mendapatkan PIRT. Pendampingan pelaku UMKM yang dilakukan Dinas Koperasi UMKM (KUMKM) Provinsi NTB cukup berhasil. Hal tersebut dari target 150 pelaku usaha produk pangan olahan sudah selesai dan sudah mendapatkan label halal. Sementara pelaku IKM binaan Disperindag NTB dari target 360 usaha, masih banyak yang belum tercapai. Rata-rata pelaku IKM terkendala dalam PIRT, karena proses yang dilalui cukup sulit. Disinilah peran penting dari pendamping. Sangat bagus dan efektip yang diterapkan Dinas KUMKM NTB. Mungkin hal serupa bisa diterapkan oleh Disperindag NTB sehingga IKM binaan mereka bisa dipermudah mendapatkan PIRT dan label halal".

\section{Lebih lanjut Majelis Ulama Indonesia}

Provinsi Nusa Tenggara Barat melalui Rauhun mengungkapkan bahwa: ${ }^{31}$

“... proses sertifikasi halal hotel dan restoran di daerah ini masih sangat minim, dari data kami, ada 300 hotel dan restoran yang belum melakukan sertifikasi halal, salah satu penyebabnya juga masih minim pemilik hotel dan restoran memproses sertifikasi halal, karena banyak pihak hotel yang ketakutan tamu mereka akan hilang manakala telah mengurus legalitas sertifikasi halal. Padahal, di sejumlah negara maju, seperti Jepang, Korea, Malaysia, dan Thailand hampir seluruh hotel mereka telah lama melaksanakan sertifikasi halal tersebut. Tren tidak optimal sertifikasi halal tersebut lantaran manajemen hotel merasa proses pengurusannya terlalu berbelit-belit dari sisi administrasi, mengingat banyak meja yang harus dilalui sebelum proses final dilakukan oleh MUI setempat. Kondisi itu kan berberbanding terbalik di sektor UMKM yang sudah banyak mengurus sertifikat halal. Hotel dan restoran ini yang

32 Hasil wawancara dengan Ketua BPPD-NTB, Afan Ahmad, Rabu, 6 September 2017 minim sekali. Pihak MUI telah mengingatkan SKPD terkait untuk proaktif melakukan sosialisasi kepada para pengelola hotel dan restoran di daerah ini, untuk mengurus sertifikasi halalnya. Pada tahun 2016 semua pembiayaan sepenuhnya ditanggung oleh APBD NTB sesuai arahan Gubernur NTB."

Berkaitan dengan sarana atau fasilitas pendukung, tercermin pula dalam pernyataan Ketua Badan Promosi Pemerintah Daerah (BPPD) NTB, Afan Ahmad yaitu: ${ }^{32}$

“...Namun ada hambatan dan tantangan dalam mengembangkan wisata syariah di NTB. Di antaranya seperti konsep atau definisi wisata syariah yang belum jelas, hotel dan restoran belum mendapat sertifikasi halal dari MUI dan belum tersedia lembaga pelatihan kepariwisataan wisata syariah..." Berdasarkan uraian pada hasil penelitian di atas, menunjukan bahwa, faktor sarana atau fasilitas pendukung mempengaruhi proses standarisasi sertifikasi halal di NTB. Hal ini sesuai dengan pandangan Soerjono Soekanto yang menuliskan bahwa: 33

"Tanpa adanya sarana atau fasilitas tertentu, maka tidak mungkin penegakan hukum akan mencapai tujuannya. Sarana atau fasilitas tersebut, antara lain, mencakup tenaga manusia yang berpendidikan dan terampil, organisasi yang baik, peralatan yang memadai, keuangan yang cukup, dan seterusnya".

Peraturan perundang-undangan akan menjadi efektif, apabila dalam pembuatan maupun implementasinya didukung oleh sarana-sarana yang memadai. Unsur-unsur mana yang harus dipenuhi agar hukum (dalam hal ini peraturan perundang-undangan) dapat digunakanan secara efektif sebagai suatu instrumen (kebijakan publik) dan batas-batas penggunaan tersebut adalah suatu langkah yang penting baik secara teoritik maupun praktis.

33 Soerjono Soekanto, op.cit. hlm. 37 
12 Pena Justisia: Media Komunikasi dan Kajian Hukum Vol. 17, No. 2, 2017

\section{Faktor Masyarakat}

Penegak hukum berasal dari masyarakat dan bertujuan untuk mencapai kedamaian di dalam masyarakat. Setiap masyarakat atau kelompok sedikit banyaknya mempunyai kesadaran hukum, persoalan yang timbul adalah taraf kepatuhan hukum, yaitu kepatuhan hukum yang tinggi, sedang, atau kurang. Adanya derajat kepatuhan hukum masyarakat terhadap hukum, merupakan salah satu indikator berfungsinya pengaturan terhadap pariwisata halal di NTB.

Ketua LPPOM MUI-NTB, Rauhun menyampaikan bahwa: ${ }^{34}$

“...Yang menjadi kendala selama ini, pihak LPPOM MUI NTB sendiri hanya disedorkan sejumlah data kosong. Karena keterbatasan pemahaman dan pengetahuan, belum mengerti bahwa harus memberikan data yang vailid. mengingat kita sebenarnya bukan pencari data, karena memang tugas kita sebagai auditor, jadi auditor itu tinggal kelapangan sehingga dengan seringnya turun kelapangan disertai sosialisasi dan pembekalan berdampak positif dalam memberikan pemahaman sertfikasi halal, yang tadinya tidak tau sekarang sudah tahu, baik masalah aturan dan mekenismenya, sehingga akan mempermudah untuk mendapatkan sertifkasi halal tersebut, MUI sangat mendukung program pemerintah pusat dan daerah terkait NTB sebagai destinasi wisata halal. Bahkan, saya menghimbau kepada pemerintah daerah bupati dan walikota di NTB untuk ikut berpartisipasi dalam menyosialisasikan program wisata halal. Saya menginstruksikan kepada seluruh pengurus MUI di Nusa Tenggara Barat untuk mendukung dan mendorong supaya wisata syariah dapat terwujut dan terselenggara, dengan semakin meningkatnya jumlah sertifikat halal. Sebagai bentuk keseriusan mendapatkan sertifikasi halal sebanyakbanyaknya, pada pertengahan tahun 2017 dan kedepan kita akan menjemput bola. Dan saya harapkan supaya SKPD ikut terlibat dalam mensosialisasikan dan memberikan dorongan kepada pihak masyatakat di da-

34 Hasil wawancara dengan Ketua LPPOM MUI-NTB, Rauhun, Selasa, 5 September 2017

35 Hasil wawancara dengan Kepala Bidang Destinasi Dinas Kebudayaan dan Pariwisata Provinsi NTB, Agus Hidayatullah, Senin 11 September 2017. earah masing-masing kabupaten kota di NTB".

Menurut Agus Hidayatullah faktor yang juga berpengaruh terhadap standarisasi pariwisata halal yaitu: ${ }^{35}$

"Kepatuhan masyarakat terhadap hukum, masih kurangnya kesadaran hukum masyarakat menjadi kendala yang sangat penting, karena pada dasarnya pariwisata halal tidak akan optimal jika tidak diimbangi oleh kesadaran masyarakat, serta upaya masyarakat untuk bersama-sama pemerintah daerah dan MUI-NTB saling bekerjasama". Ketua BPPD-NTB, Afan Ahmad, berdasarkan uraian wawancara yang di sajikan di atas, juga melihat faktor masyarakat. Walaupun faktor ini bukan sebagai satu-satunya faktor yang berpengaruh terhadap penyelenggaraan pariwisata halal. Artinya bahwa, dalam penyelenggaraan pariwisata halal memiliki kompleksitas mulai dari kelembagaan pemerintah pusat dan daerah, juga lembaga-lembaga yang diberikan kewenangan dalam pengelolaan pariwisata secara umum. ${ }^{36}$

Kurangnya kesadaran masyarakat terhadap sertifikasi halal cukup berperan akan peningkatan pariwisata halal di NTB, sehingga tugas dan kewajiban pemerintah semakin sulit apabila masyarakat juga tidak ikut ambil bagian dalam mempercepat peningkatan pariwisata halal di NTB. Dalam konteks ini perlunya reformasi di segala aspek (tidak hanya hukum) dan meningkatkan peran masyarakat sipil dalam pengawasan pembangunan adalah kunci perubahan paradigma pembangunan.

\section{Faktor Kebudayaan}

Soerjono Soekanto memandang bahwa, ${ }^{37}$ kebudayaan hukum sebagai bagian sistem hukum pada dasarnya mencakup nilai-nilai yang mendasari hukum yang berlaku, nilai-nilai yang merupakan konsepsi-konsepsi abstrak mengenai apa yang dianggap baik (sehingga dianuti) dan apa

36 Hasil wawancara dengan Ketua BPPD-NTB, Afan Ahmad, Rabu, 6 September 2017

37 Soerjono Soekanto, 2011, Faktor-Faktor Yang Mempengaruhi Penegeakan Hukum Cet.Ke-10, Raja Grafindo Persada, Jakarta, hlm. 59-60 
yang dianggap buruk (sehingga dihindari). Nilainilai tersebut, lazimnya merupakan pasangan nilai-nilai yang mencerminkan dua keadaan ekstrim yang harus diserasikan.

Maka dari itu, kebudayaan mempunyai fungsi yang sangat besar bagi manusia dan masyarakat, yaitu mengatur agar manusia dapat mengerti bagaimana seharusnya bertindak, berbuat, dan menentukan sikapnya kalau mereka berhubungan dengan orang lain. Dengan demikian, kebudayaan adalah suatu garis pokok tentang perikelakuan yang menetapkan peraturan mengenai apa yang harus dilakukan, dan apa yang dilarang.

Kebudayaan dibangun berdasar pada sejarah yang panjang, maka sedikit banyak sangat mempengaruhi pergaulan sosial masyarakat. Tingkat kepatuhan masyarakat terhadap hukum juga sangat dipengaruhi oleh budaya. Oleh karena itu, pendekatan pelaksanaan hukum harus memperhatikan budaya setempat. Ketua LPPO, MUINTB, Rauhun mengatakan bahwa: ${ }^{38}$

"Pulau Lombok dan Pulau Sumbawa kita ketahui penduduknya mayoritas muslim, kebudayaan berdasar nilai agama sudah sangat melekat di masyarakat kita, budaya masyarakat melihat makanan yang dimasak oleh orang Islam itu ya halal, masyarakat kita meyakini itu, makanya usahausaha yang punya orang Islam justru jarang yang mengajukan sertifikasi halal, dan sebaliknya, karena masakan yang dibuat oleh orang diluar Islam diragukan oleh orang Islam, mereka ingin mendapatkan kepercayaan masakan itu bebas dari bahan-bahan haram makanya mereka yang cepat mengurus sertifikasi halal. Kuatnya budaya yang berdasar nilai Islam di Provinsi NTB juga merupakan faktor yang menjadi pertimbangan penetapan NTB sebagai daerah wisata halal, akan memberikan daya tarik tersendiri bagi wisatawan untuk berkunjung ke NTB. Penetapan NTB sebagai daerah pengembangan wisata halal di Indonesia merupakan suatu langkah yang baik untuk memajukan pariwisata NTB dan menjadi contoh bagi daerah lain yang ingin menetapkan kebijakan wisata halal...".

38 Hasil wawancara dengan Ketua LPPOM MUI-NTB, Rauhun, Selasa, 5 September 2017
Sedangkan, Kepala Bidang Destinasi, Agus Hidayatullah menyampaikan bahwa: ${ }^{39}$

"Seperti yang saya katakan tadi, Pariwisata kita dikembangkan berdasar kondisi budaya yang memiliki nilai-nilai Islam, kultur masyarakat kita yang menganggap pariwisata halal itu tidak perlu sertifikat halal karena mayoritas penduduk muslim harus diluruskan, maksud pariwisata halal ini kan menjamin kita semua, agar wisatawan merasa aman, kalau mereka merasa aman itu artinya meningkat pula citra kita dan masyarakat sendiri yang merasakan hasilnya" Dengan demikian, sistem pengetahuan lokal sangat dipengaruhi oleh budaya, hal ini disamping sebagai kendala juga mencerminkan kearifan tradisi budaya suatu masyarakat dapat dijadikan sebagai alternatif untuk memecahkan masalahmasalah yang dihadapi masyarakat, khususnya dalam memanfaatkan sumber daya alam, ekonomi dan sosial yang tersedia guna memajukan pariwisata halal di NTB. Pemberdayaan masyarakat melalui sosialisasi atau pembimbingan merupakan faktor yang mempengaruhi tingkat kesadaran masyarakat guna mengarah pada perubahan perilaku.

Berdasarkan uraian faktor-faktor yang mempengaruhi standarisasi pariwisata halal di NTB di atas, berdasar hasil penelitian ditemukan masalah pokok terletak pada faktor-faktor yang mungkin mempengaruhinya adalah faktor hukum, faktor penegak hukum (struktur hukum), faktor sarana atau fasilitas pendukung, faktor masyarakat dan faktor kebudayaan.

Mengahadapi beberapa faktor tersebut upaya pembangunan sumber daya manusia merupakan instrumen utama dalam pengembangan penyelenggraan pariwisata halal di NTB. Berdasarkan Indeks Pembangunan Manusia (selanjutnya disingkat IPM) yang dikeluarkan oleh Badan Pusat Statistik pada tahun 2016, NTB berada pada

39 Hasil wawancara dengan Kepala Bidang Destinasi Dinas Kebudayaan dan Pariwisata Provinsi NTB, Agus Hidayatullah, Senin 11 September 2017. 
14 Pena Justisia: Media Komunikasi dan Kajian Hukum

Vol. 17, No. 2, 2017

status sedang dengan IPM 65,81.40 Pendekatan pembangunan manusia menggabungkan aspek produksi dan distribusi komoditas, serta peningkatan dan pemanfaatan kemampuan manusia. Pembangunan manusia melihat secara bersamaan semua isu dalam masyarakat-pertumbuhan ekonomi, perdagangan, ketenagakerjaan, kebebasan politik ataupun nilai-nilai kultural-dari sudut pandang manusia. Dengan demikian, pembangunan manusia tidak hanya memperhatikan sektor sosial, tetapi merupakan pendekatan yang komprehensif dari semua sektor.

Wicipto Setadi mengatakan bahwa dalam rangka pembangunan hukum nasional, maka diperlukan pula adanya suatu Grand Design Sistem dan Politk Hukum Nasional yang jelas yaitu sebuah desain komprehensif, yang menjadi pedoman bagi seluruh stakeholders, yang mencakup seluruh unsur dari mulai perencanaan, legislasi, diseminasi dan budaya hukum masyarakat. Grand Design Sistem dan Politk Hukum Nasional merupakan guide line komprehensif, yang menjadi titik fokus dan tujuan seluruh stakeholder pembangunan hukum, yang mencakup desain struktur pembangunan hukum secara utuh. Grand design harus diawali dengan pemikiran paling mendasar, sebagai berikut: 41

a. Pembangunan hukum harus mencakup: Asas, Norma, Insttusi, proses-proses dan penegakkannya dengan tanpa mengabaikan budaya hukum;

b. Dalam rangka harmonisasi hukum, diperlukan suatu mekanisme legislasi yang lebih sistemik, komprehensif dan holistk;

c. Konsistensi pada hirarki regulasi yang berpuncak pada konsttusi.

d. Pengabdian kepada kepentngan nasional sebagai pilar untuk tercapainya tujuan hukum, yaitu terciptanya keadilan dan ketertban dalam rangka negara kesejahteraan.

e. Grand design dilakukan per sektor hukum. Dalam rangka keadilan dan kepastan hukum,

40 Badan Pusat Statistik, “Indeks Pembangunan Manusia 2016". Lampiran 3, hlm, 110, Dikutip dari laman: https://www.bps.go.id/index.php/publikasi/index?Publi kasi_page $=2$

41 Wicipto Setadi, Pembangunan Hukum Dalam Rangka Pe ningkatan Supremasi Hukum, Jurnal Rechtsvinding, Vol. 1 No. 1, April 2012. Jakarta: Badan Pembinaan Hukum pembangunan hukum harus dilihat secara utuh, yang tdak terlepas dari sejarah.

Beberapa hal di atas, perlu melandaskan pada pandangan Bernard Arief Sidharta yang menyatakan bahwa Tatanan hukum yang terbentuk secara alami di dalam suatu masyarakat atau yang dibentuk oleh unsur-unsur pembentuk hukum yang berasal dari dalam masyarakat itu sendiri dan bukan oleh unsur luar, akan mencerminkan pandangan hidup yang berinteraksi dengan keyakinan keagamaan yang dianut di dalam masyarakat tersebut. Hukum yang terbentuk dengan cara demikian akan dirasakan adil oleh masyarakat karena sesuai dengan kesadaran hukum rakyat setempat. ${ }^{42}$

\section{PENUTUP}

\section{Kesimpulan}

Pelaksanaan standarisasi pelayanan pariwisata halal di NTB dilaksanakan berdasar Perda NTB No. 2 Tahun 2016 tentang Pariwisata Halal atas kekhususan daerah sebagaimana diatur dalam UU No. 23 Tahun 2014 tentang Pemerintahan Daerah, peraturan perundang-undangan dibidang pariwisata halal mengatur meliputi destinasi dan industri pariwisata. Standarisasi pada destinasi dilakukan oleh Dinas Kebudayaan dan Pariwisata NTB melalui pemenuhan fasilitas umum sesuai pariwisata halal. Standarisasi pada industri pariwisata halal dilakukan Dinas Kebudayaan dan Pariwisata, Dinas Perindustrian dan Perdagangan dan Dinas Kesehatan, serta MUI-NTB sebagai lembaga berwenang mengeluarkan sertifikat halal. Pelaksanaan standarisasi melalui sertifikasi halal sektor industri yang dikeluarkan oleh MUI-NTB terjadi peningkatan antara tahun 2012 sampai dengan tahun 2016.

Faktor-faktor yang mempengaruhi pelaksanaan standarisasi pelayanan pariwisata halal di

Nasional (BPHN) dan Kementerian Hukum dan HAM RI, hlm. 11-12

42 Bernard Arief Sidharta, Pembangunan Hukum Dewasa Ini di Indonesia, Digest Epistema, Vol. 2/2012, hlm. 5 Dikutip dari laman: http://epistema.or.id/wp-content/uploads/ 2015/07/Digest_Epistema_vol_2-2012.pdf, 
NTB meliputi: Pertama, faktor hukum ditunjukan melalui peningkatan sertifikasi halal sejak tahun 2015, faktor hukum sebagai penghambat yaitu kurangnya pengaturan khusus pariwisata halal. Kedua, faktor struktur yang mempengaruhi peningkatan standarisasi adalah kelembagaan yang terintegrasi dalam penyelenggaraan pariwisata halal dan diberikannya kewenangan khusus terhadap MUI-NTB, faktor struktur yang menghambat yaitu ketidakpahaman lembaga-lembaga terkait terhadap konsep wisata syariah, dan masih terbatasnya LPH yang dapat membantu kinerja MUI-NTB. Ketiga, faktor sarana atau fasilitas pendukung adalah belum tersedia lembaga pelatihan kepariwisataan wisata syariah, proses administrasi yang tidak efisien, dan minimnya pramuwisata halal. Keempat, faktor masyarakat sebagai penghambat yaitu keterbatasan pemahaman dan pengetahuan masyarakat dan pelaku usaha pada konsep dan proses sertifikasi halal. Kelima, faktor kebudayaan yaitu sebagai provinsi mayoritas penduduk beragama Islam yang berdasar nilai Islam.

\section{Saran}

Pengembangan pariwisata halal diperlukan percepatan pemenuhan fasilitas umum pada destinasi pariwisata, dan sektor industri yang masih minim sertifikasi halal perlu didorong melalui model pendampingan oleh Pemerintah Daerah NTB dalam hal ini Dinas Kebudayaan dan Pariwisata NTB, Dinas terkait dan lembaga non-pemerintah MUI-NTB untuk mempermudah proses administrasi serta skema pembiayaan yang berimbang. Peran kelembagaan dalam penyelenggaraan pariwisata halal, perlu ditingkatkan melalui peningkatan kualitas sumber daya manusia agar dapat menerapkan cara-cara atau bentuk sosialisasi atau penyuluhan yang efektif guna memberikan pemahaman yang utuh terhadap masyarakat, peningkatan pengawasan melalui inspeksi mendadak yang melibatkan masyarakat, dalam penerapan hukum perlu peningkatan pemahaman lembaga-lembaga non-pemerintah antara lain BPPD-NTB, ASITA, HPI, agar dapat ikut secara aktif memberikan pemahaman kepada masyarakat dan pelaku usaha berkaitan dengan konsep wisata halal dan pentingnya standarisasi halal melalui sertifikasi halal.

Berdasarkan pada faktor-faktor yang mempengaruhi pada terhambatnya pelayanan pariwisata halal. Maka diperlukan untuk melakukan langkah: Pertama, pada faktor hukum penguatan substansi hukum di atas Perda NTB No.2 Tahun 2016 dalam mendukung pariwisata halal, yaitu Pemerintah Pusat perlu mengeluarkan peraturan teknis diantaranya PP atau Permen untuk memperkuat dan memberikan kejelasan hukum terhadap konsep pariwisata halal secara teknis. Selain itu pengaturan yang memberikan ruang terhadap penguatan kelembagaan daerah dalam pengelolaan pariwisata. Kedua, faktor struktur melalui penguatan kapasitas dan koordinasi aktif lembaga-lembaga yang diamanatkan oleh Perda, melibatkan Lembaga Pemeriksa Halal yang dapat membantu kinerja MUI-NTB, seperti melibatkan ormas Islam lain seperti Muhammadiyah, NU dan NW yang memiliki lembaga kajian pangan serta Perguruan Tinggi di NTB. Ketiga, faktor sarana atau fasilitas pendukung perlu direalisasikan lembaga pelatihan kepariwisataan wisata syariah, proses administrasi yang efisien, dan penambahan dan pembinaan pramuwisata halal. Keempat, faktor masyarakat dan faktor kebudayaan disikapi dengan optimalisasi pemberdayaan masyarakat, dapat menggunakan metode sosialisasi atau pendampingan yang intens melibatkan seluruh elemen, lembaga pendidikan dan lembaga swadaya masyarakat

\section{DAFTAR PUSTAKA}

Asri. "Perlindungan Hukum Bagi Konsumen Terhadap Produk Pangan Yang Tidak Bersertifikat Halal." Jurnal IUS (Kajian Hukum dan Keadilan) 4. 2 (2016).

Badan Perencanaan Pembangunan Nasional, "Visi Dan Arah Pembangunan Jangka Panjang (PJP) Tahun 2005 - 2025", Dikutip dari laman:

https://www.bappenas.go.id/files/1814/2 057/0437/RPJP_2005-2025.pdf 
16 Pena Justisia: Media Komunikasi dan Kajian Hukum

Vol. 17, No. 2, 2017

Badan Pusat Statistik, "Indeks Pembangunan Manusia 2016". Lampiran 3, hlm, 110, Dikutip dari laman:

https://www.bps.go.id/index.php/publika si/index?Publikasi_page $=2$

Fajar, Mukti \& Achmad, Yulianto. 2010. Dualisme Penelitian Hukum Normatif-Empiris. Yogyakarta: Pustaka Pelajar;

Harris, J.W. 1993. Legal Philophies. London. UK: Butterworths.

Kusumaatmadja, Mochtar. 2002. Konsep-Konsep Hukum Dalam Pembangunan (Kumpulan Karya Tulis). Bandung: Penerbit Alumni. ;

Marzuki, Peter Muhamad. 2005. Penelitian $\mathrm{Hu}$ kum. Cet. ke-7. Jakarta: Kencana Prenada Media Group;

Rahardjo, Satjipto. 1996. Ilmu Hukum. Bandung: Citra Aditya Bakti;

Soekanto, Soerjono. 2011. Faktor-Faktor Yang Mempengaruhi Penegakan Hukum. Cet. Ke10. Jakarta: Raja Grafindo Persada.

Sunaryo. Bambang. 2013. Kebijakan Pembangunan Destinasi Pariwisata; Konsep dan Aplikasinya di Indonesia. Yogyakarta: Gava Media.

Sidharta, Bernard Arief. "Pembangunan Hukum Dewasa Ini di Indonesia”. Digest Epistema. Volume 2/2012. Dikutip dari laman: http://epistema.or.id/wpcontent/uploads /2015/07/Digest_Epistema_vol_22012.pdf.

Setadi, Wicipto. "Pembangunan Hukum Dalam Rangka Peningkatan Supremasi Hukum, Jurnal Rechtsvinding", Rechtsvinding, Vol. 1 No. 1, April 2012;

The World Bank, "Laporan Ekonomi Tri-wulanan Indonesia, Oktober 2016: Tekanan Mereda", Dikutip dari laman:

http://www.worldbank.org/in/country/in donesia/publication/indonesia-economicquarterly-october-2016.

Sekretariat Kabinet RI, "Tahun 2017 Kita Genjot Sektor Pariwisata", Dikutip dari laman: http://setkab.go.id/tahun-2017-kitagenjot-sektor-pariwisata/

"The World Halal Tourism Awards 2016 Winners", Dikutip dari laman:

http://itwabudhabi.com/halal-awards/ 2016- winners.html
"Kemenpar tetapkan tiga provinsi jadi tujuan wisata halal, Dikutip dari laman: http://www.antaranews.com/berita/5856 91/kemenpar-tetapkan-tiga-provinsi-jaditujuan-wisata-halal

"Industri Pariwisata Indonesia", Dikutip dari laman: https://www.indonesiainvestments.com/id/bisnis/industrisektor/ pariwisata/item6051? 